\title{
An analysis of the impact of non-oil exports on economic growth: Evidence from Nigeria
}

\author{
Lawali Bello Zoramawa ${ }^{a}$, Machief Paul Ezekiel ${ }^{b}$, Salisu Umar ${ }^{\text {* }}$ \\ ${ }^{a}$ Department of Curriculum Studies, Sokoto State University, Nigeria, Lawalbzoro@hotmail.com \\ bMarketing Department, First City Monument Bank (FCMB) BirninKebbi, Kebbi State, Nigeria,thispaul12@yahoo.com \\ ${ }^{c}$ Department of Economics, Aminu Saleh College of Education Azare, Bauchi State, Nigeria, Salisuumar09@yahoo.com \\ ${ }^{*}$ Corresponding author.
}

Received: 4 November 2019, revised: 11 January 2020, accepted: 16 January 2020, published: 20 January 2020.

\begin{abstract}
The study assessed the contribution of the non-oil sector to the economic growth in Nigeria between the periods 1981 and 2019. The study employed the ARDL bound test for cointegration to analyze the direction among the variables under review. The results of the analysis revealed that there is a negative and statistically significant relationship between non-oil exports (NOE) and economic growth (RGDP) in Nigeria during the period under investigation in the long-run for manufacturing (MANX) and solid mineral (SOLX), except for agricultural export (AGRX). There is also a bidirectional causal relationship between non-oil exports and economic growth in Nigeria during the same period. The study, therefore, recommended that the Nigerian government and other stakeholders should make a country's non-oil export commodities more attractive and competitive in the global market which will prompt the demand for Nigeria's non-oil goods at the international market.
\end{abstract}

Keywords: non-oil exports, economic growth, economic performance, ARDL.

JEL codes: 012,014

\section{INTRODUCTION}

The debate concerning the role of foreign trade as one of the main determinants of economic growth goes back to the classical economic theories by Adam Smith and David Ricardo (Abou-Strait, 2005). From the foregoing foreign trade especially exports have been seen as a major tool for economic growth and development. To this end, the export promotion policy has been prioritized by many countries. The role of exports in economic growth and the relationship between the two has been subject of discussion in the academic and policy circles. Exportation is required by every economy to enhance revenue and foreign exchange to usher in economic growth and development.

Therefore, the idea of promoting non-oil exports in Nigeria is sounded well. This is because of the huge potentials that the non-oil sector presents for foreign exchange earnings; it is also a potential source of employment generation, poverty reduction and revenue generation for Nigeria, as well as a reliable source of economic diversification (Nwankwo, 2015). From the assertion above, it is thoughtful for one to simply see a reason why the non-oil export has always been mentioned as a potential source of economic growth with the ability to turn our economy into a world-class economy. It is therefore crucial for economic progress and this has informed the idea of export-led growth (Adesoji and Sotubo, 2013).

Ifeacho, Omoniyi, and Olufemi (2014) put it forward that export is a catalyst necessary for the overall development of an economy. The primary objective of export policies in any economy, according to them, is to increase the level of economic activities. It, therefore, follows that; any export-related policy that a government may design should be a policy that will drive relevant export sectors that can sustain increased export demand. Directing export policies towards the development of the non-oil export sector in Nigeria would be a good idea, as historically, established facts show that before the discovery of crude oil in the mid-sixties, the non-oil export sector was dominated by agriculture, a non-oil component, which played significant roles in the economy. 
It was the major contributor to Nigeria's Gross Domestic Product (GDP) and also the primary source of foreign exchange. However, there was a dramatic change in the structure of Nigeria's external trade from the mid-70s (the oil boom period) and upwards when crude oil succeeded in taking the place of traditional agricultural produce as the major source of government revenue. For instance, the output of export crops grew at an average annual rate of $4.7 \%$ in $1950-1957$ and $7.4 \%$ in $1960-1965$, and then declined by $17.3 \%$ in $1970-1975$. Nominal non-oil export earnings fell from N363.5 million in 1973 to N203.2 million in 1982 (CBN, 2003). The decline was even more dramatic in real terms. Oil exports, in contrast, rose phenomenally, from about N2 billion to about N8 billion in nominal terms during the same period (CBN, 2003).

The importance of the non-oil export sub-sector has continued to increase over the years especially owing to the continual recognition of the fact that the over-dependence of the Nigerian economy on oil has manifested in the adverse consequences of the vulnerability of the economy to swing in the price of oil in the international market and other external economic shocks.

\section{LITERATURE REVIEW}

Different researchers have directed their efforts towards understanding the dynamics and role of non-oil exports and trade openness on economic growth in developing countries especially Nigeria.

Abou-Strait, 2005; Opara (2010) found that exports have been useful to some countries' economic performance, an indication that the export-led growth hypothesis holds in these countries.

Olayiwola and Okodua (2009) examined the applicability of the export-led growth (ELG) hypothesis to Nigeria and the findings failed to support the export-led growth hypothesis in Nigeria. This ELG hypothesis has become a subject of discussions in academics communities, as Medina-Smith (2000) researched on Costa Rica using annualized data from 1950 to 1997 . He adopted the Johansen co-integration technique, his findings showed that the ELG hypothesis holds in this particular country but relatively small both in the short and long run. His research discovered that export is not the main driver of growth but physical investment and population mainly drove Costa Rica's overall economic performance from 1950 onward. His findings according to him "express serious doubts as regards promoting exports as a comprehensive development strategy" but waste no time to suggest that the ELG hypothesis may probably be beneficial to few or limited less developed countries.

Dreger and Herzer, (2011) carried out a research on examination of the ELG hypothesis using panel cointegration techniques to a production function with non-export as GDP as the dependent variable, sampling across 45 developing countries, the result shows that in the short run exports have a positive effect on GDP and negative on the average in the long run. The cross-country differences in long-run results that led to average negative results are attributed to the difference in primary export dependence and labor market regulations. The importance of export in economic growth is an issue that has generated issues drawing wider attention of several studies with mix opinions and findings.

Olayiwola and Okodua (2009) investigated the dynamic interaction among Foreign Direct Investment (FDI), Non-oil exports and GDP using the concept of variance decomposition and impulse response analysis, his findings showed that policy shocks to FDI, non-oil exports and Nigeria's economic growth do not show immediate response in the desired direction.

Ulakpa (2013), analyzed the impact of non-oil exports on Nigerian economy from 1986 to 2010 given the potentially important role non-oil export can play in diversifying Nigerian economy away from crude oil exports, Using multiple regressions, the empirical result from this study showed non-oil export has a significantly positive relationship with Nigerian economic growth. Government expenditure, on the other hand, was not statistically significant to the Nigerian economy. This empirical finding shows that non-oil export if well harnessed will create employment and brings about economic growth and development.

Abogan, Akinola, and Baruwa (2014) investigated the non-oil and its impact on Nigerian economic growth from 1980 to 2010 using OLS methods involving ECM, over-parameterization and parsimonious. The findings from the study indicated that non-oil export has a positive impact on economic growth during the period under study. The impact was moderate though, as a unit increase in non-oil export increased economic growth by $26 \%$ during the period under review. The research went further to warn of an imminent collapse of the sector soon, except if immediate serious policy measures are taken to strengthen the sector. Their findings and predictions speak volumes of physical reality on the ground in Nigeria, especially given the fact that currently, crude oil dominates the exports of Nigeria.

Moreover, due to the importance of the non-oil export sector, several studies such as Adesoji and Sotubo (2013) and Ulakpa (2013) were carried out to determine its influence on economic growth in Nigeria. However, these studies have failed to address certain issues. For example, Adesoji and Sotubo (2013) concentrated on 
agricultural and mineral resources only; Ulakpa (2013) covered only a period of 24 years and could not consider some macroeconomic factors affecting the economic growth of Nigeria as the study only considered non-oil export revenue and government expenditures. Another study by Abogan, et al (2014) only considered two macroeconomic factors: Inflation rate and Exchange rate.

In research by Ifeacho, Omoniyi, and Olufemi (2014) used Per Capita Income as a proxy for economic growth and failed to disaggregate the non-oil export into the various components that make up the non-oil export sector just as the above-mentioned researchers. This study is therefore set out to fill in these gaps such as incorporating relevant variables, covering the larger period and disaggregating the non-oil exports into various components to have a robust result that can be useful in economic decision making.

Ajie, Uzomba, and Chukwu (2013) empirically analyzed economic growth through the lens of non-oil export in Nigeria from 1970 to 2008 and the overall objective of the study was to ascertain the influence of non-oil export on GDP with money supply and credit to the private sector as intervening variables. The OLS regression method, cointegration test, and error correction technique were employed. The result of the findings revealed that non-oil export and money supply has a positive relationship with economic growth. Their findings imply that an investment in non-oil export or an increase in non-oil export and an increase in the money supply would increase economic growth significantly and vice versa. Again, the study revealed that credit to the private sector has a negative relationship with economic growth during the period under review. But it was noted that all the variables involved in this research were insignificant at a $5 \%$ level of significance; an indication that non-oil export contribution to economic growth was weak from 1970 to 2008, though positive. The study recommended that based on the findings, there should be a massive investment both in the real sector most especially the agriculture and manufacturing sector to increase non-oil output for export, and also, an increased money supply to make funds available at a cheaper rate for investment.

Ifeacho, et al (2014) investigated the effect of non-oil export on the economic development of Nigeria on the backdrop of its mono-economy nature and the need to diversify. They used per capita income as a proxy for economic development and expressed it as a function of non-oil export volume, trade openness, exchange rate, capital formation, and inflation rate. Applying the Ordinary Least Square Estimation Technique, it was found that non-oil export has a positive and significant relationship with per capita income.

The findings indicate that if the non-oil export volume is increased it is going to lead to a significant improvement in Nigerian's level of economic development. The remaining variables do not have an individual significant impact on economic development; however, the findings showed that the joint influence of the variables significantly influenced economic development within the period under study. Again, the result revealed that trade openness has a negative relationship with per capita income; a clear indication that Nigeria did not benefit from trading with outside economies during the period under review.

They argued that Nigerian's trading partners gained more from trade deals within the period of this research than Nigeria. They, therefore, recommended a complete overhaul of trade policies and terms of trade if the country must promote non-oil export.

Some empirical studies on the impact of non-oil export on economic growth in Nigeria have been put forward. Some of these studies on global integration were:

Okpokpo, Ifelunini, and Osuyali (2014) investigated the potency of globalization as a tool for economic growth in Nigeria. They made use of the non-oil sector (Agriculture and Manufacturing) as a point of reference with data spanning from 1970 to 2011, they adopted the OLS regression method. The findings of the study showed that global integration has a very insignificant impact on non-oil export in Nigeria within the period of 1970 to 2011. These findings, therefore, necessitated a conclusion that global integration otherwise known as globalization has not been a potent driver of growth of non-oil export in Nigeria. Thus, they recommended that the provision of well functional infrastructures by the government as well as a consistent policy framework and a true demonstration of political will in the development of non-oil export by encouraging foreign and domestic investment into the non-oil sub-sector. A deep look into the findings in this study may reveal that Nigerian outputs from non-oil sector are mostly unprocessed agricultural and/or solid minerals goods with little or no added value, and the terms of trade deals that developing countries like Nigeria usually entered into with advanced countries are mostly unfavorably coupled with unstable currencies of the developing nations. Countries characterized by such imperfections may find it difficult to benefit from globalization.

Okoh (2004a) employed vector error correction model to investigate the implications of Nigeria's membership of the World Trade Organization (WTO); how its policies and trade agreements have affected the Nigerian nonoil exports, which hitherto had dwindled from an average of $7 \%$ in around 1970 and 1985 to $4 \%$ from 1986 to 2000. 
Findings from the study revealed globalization has a positive but insignificant relationship with non-oil export both in the long and short run. On the other hand, increases in imports of capital inputs have a positive impact on non-oil export growth. Their findings imply that Nigeria did not gain from global integration as her trading partners (exporters of capital inputs into the Nigerian market) gained during the period under study. The study suggested that Nigeria should look inward in her quest for a solution on declining non-oil export and also, renegotiate on terms and agreements of trade with her trading partners as the world is fast becoming integrated.

Comparing the effect on the overall economic growth, in their research, Rodrignes and Rodrick (1999) discovered that to date there is no convincing empirical evidence that significantly supports the argument for trade openness. In their conclusion, they agreed that openness to trade in the form of the lower tariff as well as the removal of non-tariff barriers to trade does not result in economic growth contrary to some beliefs that openness leads to economic growth.

The above findings indicate that trade openness has not worked to the advantage of Nigeria's non-oil exports and other developing countries. This may be attributed to the nature of goods these countries produce and trade at the international market. It is a well-known fact that primary products mostly unprocessed ranging from solid minerals to agricultural products account for a larger proportion of developing nations' non-oil export especially Nigeria.

This calls for a study of the Nigerian non-oil sector to understand the real determinants of the demand for our non-oil exports in the foreign market. Non-oil exports from other sectors aside from solid minerals and agriculture are small as scholars such as Uniamikogbo (1996) argued that the share of Nigeria's non-oil merchant goods in the international market specially manufactured goods are relatively insignificant compared to other advanced countries. It is in this that Nigeria must look inward and develop her manufacturing sector to be able to compete in the world market where terms of trade do not favor countries with primary products. The nature of trade policies adopted by our trade partners coupled with the domination of our export products (which are majorly primary goods) may also be attributable to the current challenge faced by the non-oil export sector in developing countries like Nigeria.

Ezike and Ogege (2012) in their research on the effect of trade policies on non-oil exports in Nigeria and the performance of non-oil exports sector for the period of 1970 to 2010 using least square techniques and correlation, their findings revealed a negative relationship between the trade policies and the non-oil in Nigeria suggesting that Nigeria's trade policies have not been encouraging the non-oil sector. They further opined that there is the need to review Nigeria's export promotion policy especially concerning non-oil exports as this will help in mobilizing the vast unused or unexplored potentials of the sector.

To bring succor to the non-oil exports Sanusi (2003) suggests that if urgent action is not taken, the unimpressive performance of the sector may continue. That there is the need to reappraised the thrusts and contents of relevant policies and commitment to their total implementation to help improve development in the sector.

Usman and Salami (2008), evaluated the contribution of the Nigerian export-import (NEXIM) to export growth performance in Nigeria between the period of 1990 to 2005 using OLS method they found that non-oil exports performance within the period under review as not encouraging in spite of the introduction of various policies.

Chukuigwe and Abili (2003) used OLS estimation procedure to examine the impact of monetary and fiscal policies on non-oil exports in Nigeria within 1974 to 2003; they found out that monetary policy (proxy by interest rate and exchange rate) and fiscal policy (proxy by budget deficits) have negatively impacted on the non-oil exports of the country. This reveals that past government policies have been ineffective in promoting the nonoil sub-sector within the study period. They recommended that Nigeria should work on stabilization of her macroeconomic environment, improves on infrastructural facilities, rationalized government role, improve on export promotion and find ways of stimulating the demand for Nigeria's non-oil goods and services in the world market.

\section{METHODS}

The model used in this study is the multiple regression analysis. The theoretical bases of this model are found in the works of Bremer (2012), according to him, the model describes how a single response variable, say $Y$ depends on many predictor variables, say $\mathrm{X} 1, \mathrm{X} 2, \ldots . \mathrm{Xn}$

This according to Bremer (2012) this can also be written as:

These are expressed as follows:

$$
Y=\beta 0+\beta 1 \times 1+\beta 2 \times 2+\cdots \beta n x n+U
$$




$$
\begin{gathered}
R_{\text {GDP }}=\beta_{0}+\beta_{1} A G R X_{t}+\beta_{2} \text { MANX }_{t}+\beta_{3} \text { SOLMX }_{t}+\mu_{t}(2) \\
R G D P_{t}=\beta_{0}+\beta_{1} \text { OPENS }_{t}+\beta_{2} I N F_{t}+\beta_{3} \text { EXR }_{t}+\mu_{t}
\end{gathered}
$$

Where RGDP, is the real Gross Domestic Product, AGRX is the Agric Export, SOLMX is the Solid Mineral Exports, OPENS, is the Openness, while INF and EXR are Inflation and Exchange Rate respectively and $\beta$ is the beta sign, ut the white noise.

Also, different techniques of data analysis were used in carrying out this empirical analysis on the assessment of the contribution of non-oil export and economic growth in Nigeria. These techniques include the autoregressive distributed lag (ARDL) models, error correction method (ECM), vector autoregressive (VAR) models, vector error correction method (VECM), simultaneous equation model and the Johansen cointegration approach. In analyzing the relationship between non-oil export and economic growth in Nigerian this research work employs the autoregressive distributed lag (ARDL) model.

The ARDL model is given as:

$$
\mathrm{Yt}=\mathrm{m}+\alpha 1 \mathrm{yt}-1+\beta 0 \mathrm{xt}+\beta 1 \mathrm{xt}-1+\mathrm{ut},(4)
$$

Where yt and xt are stationary variables, and ut is white noise. The White-noise process: A sequence $\{u t\}$ is a white-noise process if each value in the sequence has a mean of zero, a constant variance, and is serially uncorrelated. The sequence $\{u t\}$ is a white-noise process if for each period $t$,

$$
\begin{gathered}
E(u t)=E(u t-1)=\cdots=0 \\
E(u 2 t)=E(u 2 t-1)=\cdots=\sigma 2 \\
E(\text { utut-s })=E(\text { ut }- \text { jut }-j-s)=0, \text { for all } u
\end{gathered}
$$

\subsection{Autoregressive Distributed Lag Bound Testing Approach}

To empirically analyze the long-run relationship and short-run dynamic interactions among the variables of interest (Real Gross Domestic Products, agricultural component of non-oil export, manufacturing component of non-oil export, the solid mineral component of non-oil export, exchange rate, inflation rate, and trade openness) ARDL was applied. A further advantage of the ARDL model over previous and traditional cointegration methods is: All variables of the model are assumed to be endogenous and the short-run and longrun coefficients of the model are estimated simultaneously (Nikolaos, 2011). The ARDL approach to cointegration analysis involves the estimation of the Unrestricted Error Correction Model (UECM). Hence the ARDL model for testing the relationship between non-oil export, trade openness and economic growth can be written as:

ADRL equation for the First model

$$
\begin{aligned}
& \Delta M A N X_{t}=\alpha_{0}+\alpha_{1} \text { MANX }_{t-1}+\alpha_{2} \text { AGRX }_{t-1}+\alpha_{3} \operatorname{SOLMX}_{t-1}+\sum_{n=i}^{m=1} \beta_{1} \Delta A G R X_{t-i}+\sum_{n=i}^{m=1} \beta_{2} \Delta \operatorname{MANX}_{t-i}+\text { (6) } \\
& \sum_{n=i}^{m=1} \beta_{3} \Delta \operatorname{SOLMX}_{t-i}+\mu_{t}
\end{aligned}
$$

where RGDP is the real Gross Domestic Product, AGRX is the Agric Export, SOLMX is the Solid Mineral Exports, OPENS, is the Openness, while INF and EXR are Inflation and Exchange Rate respectively and ut is a white-noise, $\Delta$ is the difference parameter, $t$ is time period, and $\alpha$ and $\beta$ are the respective parameters of the model.

ARDL Equation for Second Model

$$
\begin{gathered}
\triangle \text { OPENS }_{t}= \\
\alpha_{0}+\alpha_{1} \text { OPENS }_{t-1}+\alpha_{2} I N F_{t-1}+\alpha_{3} \text { EXR }_{t-1}+\sum_{n=i}^{m=1} \beta_{1} \Delta \text { OPENS }_{t-i}+ \\
\sum_{n=i}^{m=1} \beta_{2} \Delta I N F_{t-i}+\sum_{n=i}^{m=1} \beta_{3} \Delta E X R_{t-i}+\mu_{t} \\
\Delta I N F_{t}=\alpha_{0}+\alpha_{1} I N F_{t-1}+\alpha_{2} \text { OPENS }_{t-1}+\alpha_{6} E \operatorname{EXR}_{t-1}+\sum_{n=i}^{m=1} \beta_{1} \Delta O P E N S_{t-i}+ \\
\sum_{n=i}^{m=1} \beta_{2} \Delta I N F_{t-i}+\sum_{n=i}^{m=1} \beta_{3} \Delta E X R_{t-i}+\mu_{t}
\end{gathered}
$$




$$
\begin{aligned}
& \Delta E X R_{t}=\alpha_{0}+\alpha_{1} E_{X R_{t-1}}+\alpha_{2} I N F_{t-1}+\alpha_{3} \text { OPENS }_{t-1}+\sum_{n=i}^{m=1} \beta_{1} \Delta O P E N S_{t-i}+ \\
& \sum_{n=i}^{m=1} \beta_{2} \Delta I N F_{t-i}+\sum_{n=i}^{m=1} \beta_{3} \Delta E X R_{t-i}+\mu_{t}
\end{aligned}
$$

where $\Delta$ is the first difference operator, $\alpha_{0}$ is the drift component, $\alpha_{1}$ to $\alpha_{3}$ in each equation represent the coefficients of level lagged value of the explanatory variables captured in the model, and $\beta_{1}$ to $\beta_{3}$ in each equation, are the vector of the coefficient of the first difference lagged values of the variables captured in the model.

From the first until the eighth expression $\left(\beta_{1}\right.$ to $\left.\beta_{3}\right)$ on the right-hand side correspond to a long-run relationship. The remaining expressions with the summation sign $\left(\alpha_{1}-\alpha_{3}\right)$ represent the short-run dynamics of the model.

\section{ANALYSIS AND RESULTS}

It is important to check the time series property of the variables before estimating the model to avoid the spurious result. Table 1 shows the result of the stationarity of the ADF unit root test and the results of the ARDL bound test for cointegration are presented in Table 2 and Table 3 respectively, while Table 4 presents the results of Granger Causality Test.

\subsection{Unit Root Test}

Table 1 shows the result of the ADF unit root test which indicated that all the variables are stationary at their first difference and $1 \%$ level of significance.

Table 1.ADF unit root test.

\begin{tabular}{llllll}
\hline & At Level & \multicolumn{3}{l}{ At First Difference } \\
\hline Variables & ADF Stat & $\begin{array}{l}\text { 5\% Level of } \\
\text { Significance }\end{array}$ & ADF Stat & $\begin{array}{l}\text { 5\% Level of } \\
\text { Significance }\end{array}$ & Inference \\
\hline RGDP & 1.510560 & -2.954021 & $-4.512844^{*}$ & -3.653730 & $\mathrm{I}(1)$ \\
AGRX & -1.401311 & -2.954021 & $-6.139822^{*}$ & -3.653730 & $\mathrm{I}(1)$ \\
MANX & 1.719780 & -2.954021 & $-4.605305^{*}$ & -3.653730 & $\mathrm{I}(1)$ \\
\hline
\end{tabular}

Note: ADF unit root test includes intercept only, and* indicate a 1\% level of significance.RGDP represents Real Gross Domestic Product, AGRX represents agricultural exports, and MANX represents manufacturing exports.

\subsection{Bound Test for Autoregressive Distributed Lag (ARDL) Cointegration Test}

The result presented in Table 2 above indicated that the F-statistic value of 4.9 is greater than the critical upper bound $\mathrm{F}$-statistics value of 4.35 at a $5 \%$ level of significance and $\mathrm{K}=3$ degree of freedom. Therefore, we conclude that the variables are co-integrated, meaning that the variables have a long-run relationship.

Table 2.ARDL Bound Test for Cointegration

\begin{tabular}{lllc}
\hline Test Statistic & Value & Critical Value \\
\hline F-statistic & 4.9 & Upper Bound & 4.35 \\
K & 3 & Lower Bound & 3.23 \\
\hline
\end{tabular}

Note: Critical Values were obtained from Pesaran 2001 at a $5 \%$ level of significance.

\subsection{Long-run Coefficients for ARDL}

From Table 3 above the result shows that there is a positive and significant relationship between agricultural exports (AGRX) and RGDP in the long-run at a $5 \%$ level of significance in Nigeria during the period under review. A percentage increase in AGRX will cause RGDP to increase by about $0.1 \%$. This finding is consistent with Oluwaseun (2013) who found that there is a long-run relationship between agricultural exports and economic growth. Also, the result shows that there is a negative but insignificant relationship between manufacturing exports (MANX) and RGDP in the long-run at a $5 \%$ level of significance in Nigeria. A percentage increase in MANX will cause RGDP to decrease by about $0.09 \%$.

This finding is inconsistent with Lawanson (2004) whose research discoveries indicate that some components of manufacturing export have a positive relationship with economic growth in Nigeria both in the short and long run. The result further indicated that there is a negative and statistically significant relationship between solid mineral exports (SOLMX) and RGDP in the long-run at a 5\% level of significance in Nigeria. A percentage 
increase in SOLMX will cause RGDP to decrease by about $0.15 \%$. This finding is inconsistent with David, et al (2016)who found that the value of solid mineral has a strong impact on economic development in Nigeria.

Table 3.Long-run Model (I)

\begin{tabular}{ccccc}
\hline & \multicolumn{3}{c}{ Dependent Variable: RGDP } & Prob. \\
\hline Variable & Coefficient & Std. Error & t-Statistic & 0.0053 \\
C & -4.552545 & 1.248542 & -3.646290 & 0.0077 \\
LOG(RGDP(-1)) & 0.308590 & 0.090373 & 3.414615 & 0.0288 \\
LOG(AGRX(-1)) & 0.135229 & 0.052018 & 2.599642 & 0.1169 \\
\hline
\end{tabular}

The Granger Causality theorem states that when the variables under control are co-integrated (have a long-run relationship), then there must be an error correction model (ECM) that describes the short-run relationship. The rationale behind ECM is that it specifies the speed of adjustment from the short-run equilibrium to the long-run equilibrium level (Gujirati, 2004 and Ajao\&lgbokeyi, 2013). The ARDL-ECM models are specified in equation 10 to 11 as:

$$
\begin{aligned}
& \Delta M_{A N X}=\alpha_{0}+\alpha_{1} M_{A N X} X_{t-1}+\alpha_{2} A G R X_{t-1}+\alpha_{3} S O L M X_{t-1}+\sum_{n=i}^{m=1} \beta_{1} \Delta A G R X_{t-i}+\sum_{n=i}^{m=1} \beta_{2} \Delta M A N X_{t-i}+ \\
& \sum_{n=i}^{m=1} \beta_{3} \Delta S O L M X_{t-i}+\beta 4 E C M+\mu_{t} \\
& \triangle S O L M X_{t}=\alpha_{0}+\alpha_{1} \text { SOLMX }_{t-1}+\alpha_{2} \text { MANX }_{t-1}+\alpha_{3} A G R X_{t-1}+\sum_{n=i}^{m=1} \beta_{1} \Delta A G R X_{t-i}+\sum_{n=i}^{m=1} \beta_{2} \Delta \text { MANX }_{t-i}+ \\
& \sum_{n=i}^{m=1} \beta_{3} \Delta S O L M X_{t-i}+\beta_{3} \mathrm{ECM} \mu_{t}+\mu_{t}
\end{aligned}
$$

where ECM is the error correction model.

\subsection{Long-run Coefficients for ARDL}

Table 4 presents the results of the short-run impact of the variables on the dependent variable. The coefficient of real GDP (LRGDP) has a positive and significant impact on economic growth at a $5 \%$ level of significance. Thus, a $1 \%$ increase in real GDP will lead to a $0.19 \%$ increase in economic growth. Similarly, the coefficients of Agric exports have a positive and significant impact on economic growth. Thus, a 1\% increase in Agric exports, will lead to an increase of $15 \%$ and a $26 \%$ increase in economic growth, respectively. However, the coefficient of manufacturing exports also has a positive and significant impact on economic growth at a $1 \%$ level of significance. The coefficient of error correction model $(\mathrm{ECM}(-1))$ revealed a correct sign and statistically significant which measures the speed of adjustment of the dependent variables at which equilibrium is restored. The results implied that $52 \%$ of any disequilibrium in the economic growth is corrected within a lag (one year in this study).

Table 4.Results of Short-run Coefficients

\begin{tabular}{lllll}
\hline Variable & Coefficients & Std. Error & t-statistic & p-value \\
\hline D(RGDP) & 0.001885 & 0.000777 & 2.425460 & 0.0294 \\
D(AGRX) & 0.005790 & 0.002730 & 2.121224 & 0.522 \\
D(LAGRX $(-1))$ & -0.002070 & 0.002663 & -0.777521 & 0.4498 \\
D(LAGRX(-2)) & 0.007372 & 0.001787 & 4.125370 & 0.0010 \\
D(LMANX) & 0.158346 & 0.006370 & 24.859353 & 0.0000 \\
D(LMANX(-1)) & -0.017495 & 0.007273 & -2.405591 & 0.0305 \\
ECM(-1) & -0.519423 & 0.174225 & -8.721029 & 0.0000 \\
\hline
\end{tabular}

\subsection{Granger Causality Test}

Table 5 shows that there is a bi-directional causality between agricultural exports (ARGX) and RGDP. This implies that there is a causal relationship running from ARGX to RGDP and from RGDP to ARGX at a 5\% level of significance. Also, there is a bi-directional causality between manufacturing exports (MANX) and RGDP. This implies that there is a causal relationship running from MANX to RGDP and from RGDP to MANX at a $5 \%$ level of significance. The result further indicates that there is a bi-directional causality between solid minerals (SOLMX) and economic growth (RGDP). This implies that there is a causal relationship running from SOLMX to RGDP and from RGDP to SOLXM at a $5 \%$ level of significance. Therefore, we conclude that there is bidirectional causality running from non-oil exports and economic growth in Nigeria. 
Table 5.Results for the Granger Causality Test

\begin{tabular}{lll}
\hline Null Hypothesis & F-Statistic & Prob. \\
\hline AGRX does not Granger Cause RGDP & 4.11208 & 0.0276 \\
RGDP does not Granger Cause AGRX & 14.7796 & 0.0000 \\
\hline MANX does not Granger Cause RGDP & 6.93853 & 0.0037 \\
RGDP does not Granger Cause MANX & 2.99355 & 0.0670 \\
SOLMX does not Granger Cause RGDP & 7.55296 & 0.0025 \\
RGDP does not Granger Cause SOLMX & $8.88947 \mathrm{ss}$ & 0.0011 \\
MANX does not Granger Cause AGRX & 10.3409 & 0.0005 \\
AGRX does not Granger Cause MANX & 7.21357 & 0.0031 \\
SOLMX does not Granger Cause AGRX & 36.1388 & 0.0000 \\
AGRX does not Granger Cause SOLMX & 0.00807 & 0.9920 \\
\hline SOLMX does not Granger Cause MANX & 5.11575 & 0.0131 \\
MANX does not Granger Cause SOLMX & 4.41466 & 0.0219 \\
\hline
\end{tabular}

\section{CONCLUSIONS}

The study evaluated the contribution of the non-oil exports on the economic growth of Nigeria for the period 1981 to 2019. To achieve the specific objectives of the study, the ARDL bound test for cointegration was employed to determine the long-run and short-run dynamic relationship between the variables. Based on the findings of the analysis, the following conclusions were made. Non-oil exports have positive effects on economic growth in the long-run while in the short-run it has negative and insignificant effects on economic growth in Nigeria during the period under review. Moreover, Non-oil exports solid mineral exports have negative and statistically significant effects on economic growth in the long-run and a negative but insignificant relationship in the short-run in Nigeria. Lastly, there is bi-directional causality running from non-oil exports and economic growth and from economic growth to the non-oil sector in Nigeria.

The study recommended that Nigeria should devise means of making non-oil export commodities more competitive in the international market. The study also recommended that improving the quality of non-oil export will draw attention to Nigeria's commodities, hence the high demand for Nigeria's non-oil exports; Ceteris paribus. However, there is the need to empower our standard organizations to properly monitor and ensure that only qualitative made in Nigeria non-oil export commodities are taken to the foreign market. Moreover, the government should reduce cumbersome bureaucratic bottlenecks that breed corruption in our standard organizations by compromising standards.

Lastly, the government should invest more in growing local industries and ensure that the high cost of production is reduced by ensuring that infrastructures that will help reduce the cost of production in the non-oil exports such as constant electricity supply, cheaper transportation via better roads networks, etc. are made available. But on the poor performance of openness to trade on the Nigerian economy the government should review the terms and conditions of trade usually entered into by the Nigerian government when signing trade agreements with other countries. These terms and conditions of trade must be reviewed to reflect the reality that our export commodities are mostly primary products.

Based on the limitations described earlier in chapter one and the result, the following are suggestions for future research: A research work with a study period longer than the study period used in this study should be conducted. Also, past data of Manufacturing Exports, Solid Minerals Exports, Trade Openness, Exchange rate, inflation rate and other relevant factors for Nigeria beyond the period of this study should be obtained and the same relationships could be examined using different techniques of data analysis for a period spanning the longer length of time.

\section{ACKNOWLEDGMENTS}

Lawali Bello Zoramawa would like to thank Paul Machief and Salisu Umar for their astute contribution that without it, the research may not be feasible.

\section{FUNDING}

The study is the part of the project conducted while in the University pursuing our Master's Degree of Science Economics (M.Sc. Economics) at UsmanuDanfodiyo University Sokoto, Nigeria. As colleagues, we worked together towards the realization of our common goals as academicians and it was self-sponsored and funded. 


\section{REFERENCES}

Abogan, O. P. Akinola, E. B. \&Baruwa, O. I. (2014). Non-oil export and economic growth in Nigeria (1980-2011). Journal of Research in Economics and International Finance (JREIF), 3(1).

Abou-Stait, F., (2005). Are Exports the Engine of Economic Growth? An Application ofCointegration and Causality Analysis for Egypt, 1977-2003. .African Development Bank, Economic Research Working Paper. 76.

Ajie H. A., Uzomba, P. C., \&Chukwu, S. N. (2013). Economic Growth through the Lens of Non-Oil Export in Nigeria, 1970 - 2010. Journal of Poverty, Investment and Development - An Open Access International Journal, 1.

Bremer, M. (2012). Multiple Linear Regression: Math 261A-Spring 2012; supplement multiple regression.Central Bank of Nigeria (2003). Statistical Bulletin. Abuja: Central Bank of Nigeria.

Chen, Y. Y. (2010). Autoregressive Distributed Lag (ADL) Model.

Chidinma, (2010). The Relative Impact of oil and non-oil exports on economic growth in Nigeria: 1983-2007.Caritas University Amorji-nikeEmene, Enugu.

Chukuigwe, E. C. \&Abili, I. D. (2003).An econometric analysis of the impact of monetary and fiscal policies on non-oil exports in Nigeria: 1974-2003. African Economic and Business Review.6 (2).

David, O. O., Noah, O. A., \&Agbalajobi, S. A. (2016). An Empirical Analysis of the contribution of the mining sector to economic development in Nigeria, Khazar Journal of Humanities and Social Sciences.

Dreger, C. \& Herzer, D. (2011). A further examination of the export-led growth hypothesis discussion paper. German Institute for Economic Research Mohrenstr, Berlin.

Ezike J. E \&Ogege, S (2012). Nigerian foreign trade policy: Its impact on non-oil exports. Journal of Economics and International Finance, 4(8),192-200.

Eachlf each, C.; Omoniyi, B. O. \&Olufemi, O. B. (2014). Effects of non-oil export on The economic development of Nigeria. International Journal of Business and Management Invention, 3(3), 27-32.

KyrreStensnes (2006).Trade openness and economic growth. Do institutions matter? NorskUtenrikspolitisklnstitutt $702-2$.

Lawanson T. O., \&Bankole,A.S(2004).Impact of Manufactured Goods exports on economic Growth: A dynamic econometric model for Nigeria. African Journal of Economic Policy.

Nwankwo, O (2015). Diversification of non-oil export products as a precondition for accreted real economic growth in Nigeria. International Journal of Managerial Studies and Research (IJMSR) 3 (7), 104-112.

Okoh, R. N. (2004a) Global integration and the growth of Nigeria's non-oil exports.paper presented at the African Conference 21 ñ 22, March 2004, Oxford, UK.

Okpokpo, G. U., Ifelunini, I. A. \&Osuyali, F. (2014). Is globalization a potent driver of economic growth? Investigating the Nigerian non-oil exports. Asian Economic and Financial Review, 4 (6), 781-792.

Opara, B. C. (2010). Nigerian firms' non-oil export involvement: An Economic Transformation Paradigm. European Journal of Scientific Research, 40 (4), 547-556.

Olayiwola, K. \&Okodua, H. (2009). Foreign Direct Investment, non-oil exports, and economic growth in Nigeria: a causality analysis. Asian Economic and Financial Review, 2013, 3(11), 1479-1496.

Pesaran, M., \& Shin,Y. (1999). An autoregressive lag modeling approach to co-integration analysis. In S. Strom. (ed) econometrics and economic theory in the 20th century: The Ragnar Frisch Centennial Symposium, Cambridge University Press, Cambridge.

Pesaran, M. H., Shin, Y., \& Smith, R. J. (2001). Bounds testing approaches to the analysis of level relationships. Journal of Applied Econometrics. 16.

Pritchett, L. (1996). Measuring outward orientation in the LDCs: Can it be done? Journalof Development Economics, (49), 309-55.

Rodríguez, F. \& D. Rodrik (1999).Trade policy and economic growth: A skeptic's guide to the cross-national evidence." NBER Working Paper 7081.

Sustainable development Indicator Group SDIG (1996). Working draft framework https://www.hq.nasa.gov/iwgsdi/Manufacturing.html.

Ulakpa, .N. M (2013). Impact of non-oil export on the Nigerian economy. Caritas University. Amorji-Nike Enugu.

Uniamikogbo, B. U. (1996). Import demand in Nigeria: A re-examination of the evidence". The Nigerian Economic and Financial Review, (2), 65-86.

Usman, O. A. \& Salami, A. O. (2008). The contribution of Nigerian export-import (NEXIM) bank towards export non-oil growth in Nigeria (1990-2005). International Business Management, 2 (3), 85-90. 